\title{
A SZERELÉSI FOLYAMATOK HATÉKONYSÁGÁNAK JAVÍTÁSA MTM MÓDSZERREL
}

\author{
Mezei Petra \\ BSc hallgató, Miskolci Egyetem Logisztikai Intézet \\ 3515 Miskolc, Miskolc-Egyetemváros, e-mail: mezeipetra0410@gmail.com \\ Kovács György \\ egyetemi docens, Miskolci Egyetem Logisztikai Intézet \\ 3515 Miskolc, Miskolc-Egyetemváros, e-mail: altkovac@uni-miskolc.hu
}

\begin{abstract}
Absztrakt:
A folyamatosan változó és növekvö kereslet csökkenti a termékek piacra jutásának idejét, igy a termelési rendszer rendkivüli kihivásokkal néz szembe. Fontos feladat ezért, hogy a mérnökök pontosan megtervezzék a szerelési folyamatot, amelyhez segitséget nyújtanak az MTM módszerek. A tanulmány célja az MTM (Methods Time Measurement) elemzö módszer bemutatása, amely a munkafolyamatot alapmozdulatokra bontja és a mozdulatokhoz meghatározott idöértékeket rendel. Az alapvetö elképzelés a módszer alkalmazása során az, hogy ha a munkafolyamatot a lehetö legkisebb részegységekre bontjuk, ezek idöszükséglete az egyéntöl nem, csak az alkalmazott módszertöl függ. Ennek segitségével a munkafolyamat akár elméletben még a tényleges gyártás elött leirható, és lehetöség nyílik a folyamatos javitásra, fejlesztésre. A módszer használatával egy adott szerelési munkafolyamatot fejlesztettünk, amely a cikkben egy esettanulmányon keresztül bemutatásra is kerül.
\end{abstract}

Kulcsszavak: MTM, hatékonyságnövelés, szerelési folyamat, esettanulmány

\section{Abstract:}

The increasing demand of a given product lessens it's time to be put on the market. This makes the production system face many challenges day by day. Therefore it is important for engineers to work out and plan the assembly of the device, using the help of MTM method. This study introduces the results of MTM (Methods Time Measurement). The procedure separates the basic moves used in the work process and orders an amount of time to it. The conception behind it is that if you reduce the work process to the smallest basic movements the timeframe will not as much depend on the person doing it as it will on the method he or she is doing it with. As a result the time of production becomes clear even before the assembly starts, making it that much easier to change and develop the process. We have improved an assembly processes by MTM method which introduced in the frame of a case study.

Keywords: MTM, efficiency improvement, assembly proccess, case study 


\section{Bevezetés}

Napjainkban a gyártási folyamatok hatékonyságának javítása nélkülözhetetlen a termelő vállalatok versenyképességének javítása érdekében. Számos módszer áll rendelkezésre a termelékenység javítására vonatkozóan [1]. Nyilvánvaló azonban, hogy a munkamódszerek hatékony kialakítása az egyik legfontosabb szempontja a termelékenység növelésének [2].

Habár az elmúlt években erőteljes tendencia volt a gyártás gépesítése és automatizálása, sok összeszerelési és szétszerelési műveletet még mindig nagyon gyakran manuálisan hajtanak végre. Ennek köszönhetően manapság az emberek a termelés legfontosabb részei. Az egyre szélesebb körben alkalmazott Húzó termelési filozófia, valamint a piaci verseny eredménye az, hogy a késztermékváltozatok száma nő, a gyártási sorozatok nagysága pedig csökken [3]. Ezen igények a termelési rendszerek rugalmasságát és újra konfigurálhatóságát igénylik, továbbá a megfelelő emberi közremüködést a tervezés és a gyártás során [4].

Ahhoz, hogy az emberek a lehető leghatékonyabban dolgozhassanak, a gyártási- és munkafolyamatok, valamint a munkahelyek optimális kialakítása kulcsfontosságú.

A munka pontos ütemezése azonban nem könnyủ feladat, de annak rögzítése a versenypiacon feltétlenül szükséges. Tegyük fel, hogy egy szervezet új terméket kíván gyártani. Annak ismerete, hogy mennyi időt vesz igénybe bizonyos munkafeladatok elvégzése, lehetővé teszi a menedzsment számára a személyzet, az anyagok és a berendezések kedvező kihasználásának elérését. Ez mind elengedhetetlen egy szervezet növekedéséhez.

Számos oka van annak, hogy tudni akarjuk, mennyi idő alatt kell elvégezni egy adott feladatot. Ez egyszerüen kíváncsiság is lehet. Valójában azonban a következő három szemponthoz szükséges:

- a tervezés végrehajtásához,

- a teljesítmény és a munkaciklus hosszának meghatározásához, és

- a költségek megállapításához.

A tanulmány célja, hogy az MTM (Methods Time-Measurement) módszer segítségével bemutassuk, hogy egy adott munkafolyamat még a tényleges gyártás előtt leírható. Ez alapján pedig egy egységes és pontos munkautasítás készíthető a dolgozók számára, illetve lehetőség nyílik a folyamatos javításra, fejlesztésre is. A módszer alkalmazásával egy adott szerelési munkafolyamatot fejlesztettünk, amely a cikkben egy esettanulmányon keresztül bemutatásra is kerül.

\section{A szerelési folyamatok tervezésének módszere}

A szerelés olyan müvelet, amely során az alkatrészeket, illetve a szerelési részegységeket további egységekké, gyártmánnyá kapcsoljuk össze. Az 1. ábra a szerelési folyamatok tervezésének lépéseit mutatja be.

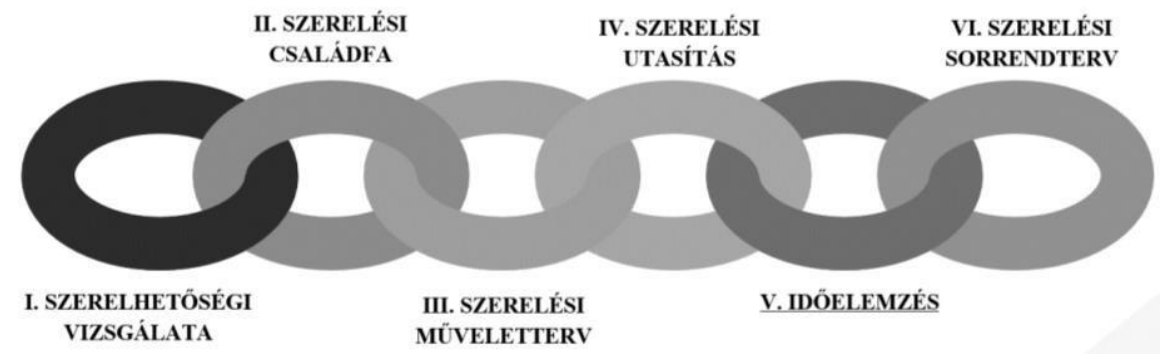

1. ábra A szerelési folyamat tervezésének szakaszai [5] 
Szerelhetőségi vizsgálatnál először is ellenőrizni kell, hogy a szerkezet elemei összeszerelhetők-e, nem akadályozzák-e a szerelést. A második feladat az egyes alkatrészek geometriai kialakításának felülvizsgálata. Végiggondolva a szerelési folyamatot, az alkatrész alakjának meg kell felelnie a tárolás és a továbbítás során jelentkező követelményeknek [6].

A szerelési családfa megmutatja, hogy a gyártmány milyen szerkezeti egységekből áll. A szerelési családfa alapján készíthető el a szerelési müveletterv. A müveletterv megadja az egyes müveletek egymás utáni sorrendjét. A szerelési utasítás részletesebb adatokkal szolgál. A múvelettervet múveletelemekre bontja és tartalmazza a müveletterv minden egyes müveletelemének részletes leírását, a müveletek elvégzéséhez szükséges szerszám, segédanyag listáját.

Az elkészült szerelési variációk közül időelemzéssel választhatjuk ki a megfelelőt. Az időelemzés célja az egyes szerelési müveletek összehangolása, az állandó ütemidő biztosítása. Magát az elemzést többféleképpen lehet elvégezni. A legegyszerübb módja a próbaszerelés, ahol stopperórával mérve megkaphatjuk a szerelés idejét. A mérést tanácsos több személlyel, többször elvégezni, hogy a mérések realitása megmaradjon. A módszer legnagyobb hibája, hogy a próbaszerelést végző mérnökök nem rendelkeznek az operátorok gyakorlottságával, valamint a tervezés ezen fázisában nem állnak rendelkezésre azok a speciális szerszámok és készülékek, amelyek egyszerüsítik és gyorsabbá teszik majd a tényleges szerelést. Nem beszélve arról, hogy nagyon sok minden befolyásolja ezt a fajta mérési módszert: milyen müszakban dolgozik a szerelést elvégző emberünk, evés előtt, vagy után vane, hány órát dolgozott már elötte és még sorolhatnánk.

\section{Időelemzés MTM módszerrel}

Az 1940-es években kialakítottak egy olyan módszert, amiben minden alapmozdulathoz egy elöre meghatározott időt rendelünk [7]. Ezt az értéket úgy határozták meg, hogy az ember 100\% teljesítménnyel képes legyen végrehajtani fáradás nélkül több órán keresztül. Ez a módszer, amellyel időelemzést végezhetünk, az MTM (Methods Time-Measarument) eljárás [8].

\subsection{A mozdulataink felépítése}

Vizsgálatok alapján megállapították, hogy a mozdulataink 80-85\%-a öt alapmozdulatból áll, s ezek sorrendje is tipikus. Ezt a mozdulatciklust alapciklusnak nevezzük (2. ábra).

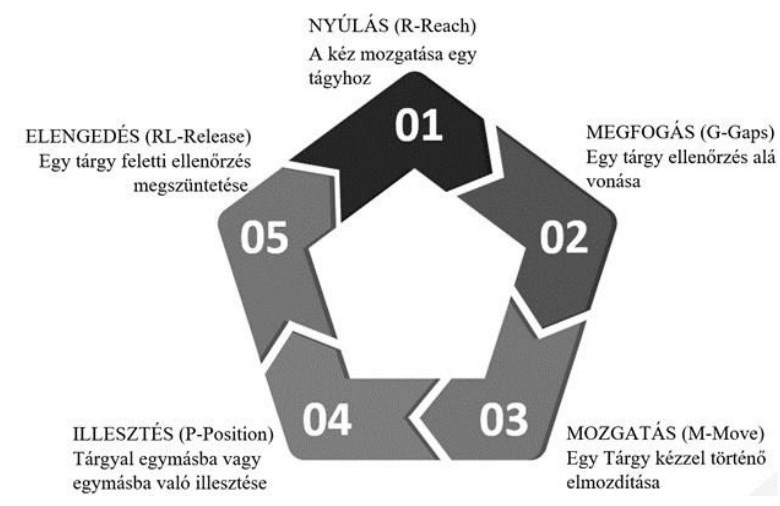

2. ábra Az MTM alapmozdulatok bemutatása [9] 


\subsection{Az MTM időegysége}

Az alapmozdulatokhoz különböző szabványos időértékeket rendeltek. Ezek az értékek, mivel többségében a másodperc töredéke alatt végbemennek, egy új időegységben, úgynevezett TMU-ban (Time Measurement Unit) vannak kifejezve. Egy másodperc 27,8 TMU-nak felel meg (1. táblázat). A müvelet elemzésekor a teljes TMU értéket át kell számítani másodpercre. A TMU értékeket a körülményekkel súlyozzuk (pontosság, méret, tömeg).

\begin{tabular}{|c|c|c|c|}
\hline TMU & $\begin{array}{c}\text { Másodperc } \\
{[\mathrm{sec}]}\end{array}$ & $\begin{array}{c}\text { Perc } \\
{[\mathrm{min}]}\end{array}$ & $\begin{array}{c}\text { Óra } \\
{[\mathrm{h}]}\end{array}$ \\
\hline 27,8 & 1 & - & - \\
\hline 1667 & - & 1 & - \\
\hline 100.000 & - & - & 1 \\
\hline
\end{tabular}

1.táblázat Alap TMU átszámítások bemutatása

\begin{tabular}{|c|c|c|c|}
\hline TMU & $\begin{array}{c}\text { Másodperc } \\
{[\mathrm{sec}]}\end{array}$ & $\begin{array}{c}\text { Perc } \\
{[\mathrm{min}]}\end{array}$ & $\begin{array}{c}\text { Óra } \\
{[\mathrm{h}]}\end{array}$ \\
\hline 1 & 0,036 & - & - \\
\hline 1 & - & 0,0006 & - \\
\hline 1 & - & - & 0,00001 \\
\hline
\end{tabular}

\section{Az alapmozdulatokhoz tartozó adatkártya-kódok részletes bemutatása}

Az MTM módszer hatékony alkalmazásának egyik feltétele a munkafolyamat pontos leírása [10]. Ezt a leírást megfelelő kódok használatával érik el minden kiválasztott alapmozgáshoz. A 2. ábrában feltüntetett alapmozgások kategóriáit és címkéit táblázatokban dolgozzuk fel.

Azért fontos, hogy kódokkal írjuk le a munkafolyamatot, mert így átláthatóbbá válik a szerelés folyamata, és így az utólagos módosítások, fejlesztések könnyebben kivitelezhetők.

\subsection{Nyúlás (R-Reach)}

2. táblázat Különbözö nyúláshosszhoz és nyúlástípushoz rendelt időegységek

\begin{tabular}{|c|c|c|c|c|}
\hline \multirow{2}{*}{$\begin{array}{c}\text { Mozgáshossz } \\
{[\mathrm{cm}]}\end{array}$} & \multicolumn{4}{|c|}{ T $\mathbf{U}$} \\
\cline { 2 - 5 } & $\mathrm{A}$ & $\mathrm{B}$ & $\mathrm{C}, \mathrm{D}$ & $\mathrm{E}$ \\
\hline 5 & 4,0 & 4,0 & 5,9 & 3,8 \\
\hline 10 & 6,1 & 6,4 & 8,4 & 6,8 \\
\hline 20 & 7,9 & 10,1 & 11,5 & 9,3 \\
\hline 30 & 9,6 & 12,0 & 14,2 & 11,8 \\
\hline
\end{tabular}

A: Nyúlás olyan egyedül álló tárgy után, amely mindig ugyanazon a helyen van.

B: Nyúlás olyan egyedül álló tárgy után, amely csekély mértékben eltérö helyen található.

C: Nyúlás olyan egyedül álló tárgy után, amely össze van keverve azonos, vagy hasonló tárgyakkal.

D: Nyúlás olyan egyedül álló tárgy után, amely nagyon kicsi, vagy óvatos kezelést igényel.

E: A kéz nyúlása, illetve áthelyezése egy meg nem határozott helyzetbe. 


\subsection{Megfogás (G-Grasp)}

3.táblázat Különböző fogástípusokhoz rendelt időegységek

\begin{tabular}{|c|c|}
\hline Kategória & TMU \\
\hline G1 A & 2,0 \\
\hline G1 B & 3,5 \\
\hline G2 & 5,6 \\
\hline G3 & 5,6 \\
\hline G4 A & 7,3 \\
\hline G4 B & 9,1 \\
\hline G4 C & 12,9 \\
\hline G5 & 0,0 \\
\hline
\end{tabular}

G1: Felvevő fogás.

G1 A: Egyedül álló tárgy megfogása az ujjak zárásával.

G1 B: Egyedül álló, kisméretü (3x3x3 mm alatti) tárgyak megfogása.

G2: Után fogás, a már kézben lévő tárgy utánigazítása.

G3: Átadó fogás egyik kézből a másikba.

G4: Kiválasztó fogás, tárgy keresése és kiválasztása egy halmazból.

G4 A: A tárgy nagyobb, mint $25 \times 25 \times 25 \mathrm{~mm}$.

G4 B: A tárgy mérete $6 \times 6 \times 3 \mathrm{~mm}$ és $25 \times 25 \times 25 \mathrm{~mm}$ közé esik.

G4 C: A tárgy kisebb, mint 6x6x3 mm.

G5: Érintő fogás, a tárgyat érintéssel is irányítani tudjuk.

\subsection{Mozgatás (M-Move)}

4. táblázat Különbözö mozgatáshoz és mozgatástipushoz rendelt időegységek

\begin{tabular}{|c|c|c|c|c|}
\hline \multirow{2}{*}{$\begin{array}{c}\text { Mozgáshossz } \\
{[\mathrm{cm}]}\end{array}$} & \multicolumn{5}{|c|}{ TMU } \\
\cline { 2 - 5 } & $\mathrm{A}$ & $\mathrm{B}$ & $\mathrm{C}$ & $\mathrm{m}-\mathrm{B}$ \\
\hline 2 & 2,0 & 2,0 & 2,0 & 1,7 \\
\hline 10 & 6,0 & 6,8 & 7,9 & 4,3 \\
\hline 20 & 9,6 & 10,5 & 11,7 & 7,1 \\
\hline 30 & 12,7 & 13,3 & 15,1 & 9,8 \\
\hline
\end{tabular}

A: A tárgyat úgy kell mozgatni, hogy vagy a másik kézhez, vagy egy ütköző álláshoz kell vinni.

B: A tárgyat megközelító, vagy meghatározatlan helyzetbe kell vinni.

C: A tárgyat egy meghatározott helyzetbe kell vinni. A célterület nagysága $12 \mathrm{~mm}$. 
Mezei, P., Kovács, Gy.

A szerelési folyamatok hatékonyságának javitása MTM módszerrel

\subsection{Elhelyezés (P - Position)}

5. táblázat Különbözö elhelyezéstipushoz rendelt időegységek

\begin{tabular}{|c|c|c|c|c|}
\hline \multirow{3}{*}{$\begin{array}{l}\text { Illesztés } \\
\text { fajtája }\end{array}$} & \multirow{3}{*}{ Jellemző } & \multirow{3}{*}{ Szimmetria } & \multicolumn{2}{|c|}{ Kezelhetőség } \\
\hline & & & $\mathrm{E}$ & $\mathrm{D}$ \\
\hline & & & \multicolumn{2}{|c|}{ TMU } \\
\hline \multirow{3}{*}{$\mathrm{P} 1$} & \multirow{3}{*}{ Laza } & S & 5,6 & 11,2 \\
\hline & & SS & 9,1 & 14,7 \\
\hline & & NS & 10,4 & 16,0 \\
\hline \multirow{3}{*}{$\mathrm{P} 2$} & \multirow{3}{*}{ Szoros } & $S$ & 16,2 & 21,8 \\
\hline & & SS & 19,7 & 25,3 \\
\hline & & NS & 21,0 & 26,6 \\
\hline \multirow{3}{*}{ P3 } & \multirow{3}{*}{ Rögzíti } & $S$ & 43,0 & 48,6 \\
\hline & & SS & 46,5 & 52,1 \\
\hline & & NS & 47,8 & 53,4 \\
\hline
\end{tabular}

P1: Laza, nyomásra nincs szükség.

P2: Szoros, enyhe nyomás kell.

P3: Rögzíti, erös nyomás kell.

S: Szimmetrikus: a tárgyat minden helyzetben egymásba lehet illeszteni.

SS: Félszimmetrikus: a tárgyat két vagy több helyzetben lehet összeilleszteni.

NS: Aszimmetrikus: a tárgyat csak egy helyzetben lehet illeszteni.

E: A kezelhetőség egyszerü.

D: A kezelhetőség nehézkes.

\subsection{Elengedés (RL - Release)}

6. táblázat Különbözö elengedéstípushoz rendelt időegységek

\begin{tabular}{|c|c|}
\hline Kategória & TMU \\
\hline RL1 & 2,0 \\
\hline RL2 & 0,0 \\
\hline
\end{tabular}

RL1: Normál elengedés az ujjak nyitásával.

RL2: Az érintkezés megszüntetésével. 


\section{A szerelési folyamat hatékonyságának javítása az MTM módszer alkalmazásával - Esettanulmány}

Az MTM módszer alkalmazásával jelentős hatékonyságjavulás érhető el, amelyet egy adott szerelési folyamaton keresztül mutatunk be. Az esettanulmány célja annak bizonyítása, hogy fontos pontosan megtervezni a szerelési folyamatot, és nem elég csupán csak a tapasztalati úton szerzett tudással összeszerelni az adott terméket.

Az összeszerelni kívánt termék három csavarból, kilenc alátétből, két lemezből és három anyacsavarból áll (3. ábra).
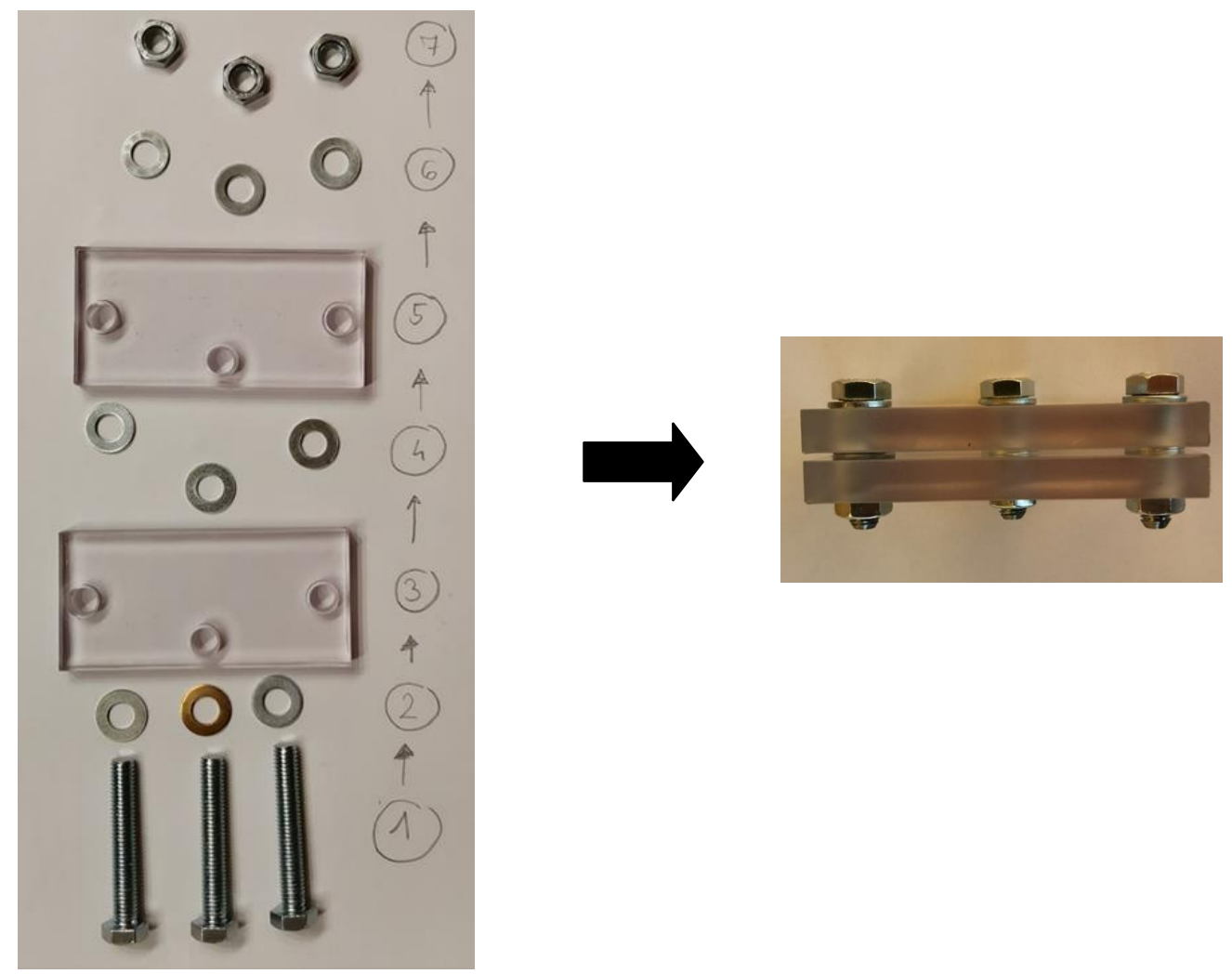

3.ábra A gyártmány felépitési sorrendje, illetve az összeszerelt késztermék

\subsection{A szerelési folyamat elvégzése az MTM módszer alkalmazása nélkül}

A szerelési folyamat elvégzése először minden elötervezés nélkül, egyszerü betanítással történt. A kísérletben résztvevő dolgozók úgy szerelték össze az alkatrészeket, ahogy nekik kényelmes (ám ez nem jelenti azt, hogy egyben hatékony is). Ezután egy rövid begyakorlás után le lett mérve a szereléshez szükséges idejük. 


\section{A szerelési feladat kiindulási állapota:}

- az alkatrészek tárolására három, egymás mellett álló doboz áll rendelkezésre, a szerelést végrehajtó személytöl $30 \mathrm{~cm}$ távolságban,

- az egyik doboz a csavarokat, a másik az alátéteket, a harmadik pedig a lemezeket tartalmazza,

- a dolgozó a negyedik dobozba a kész szerelvényeket gyüjti össze.

A szerelést végző személyek az esetek többségében ösztönösen a következő mozdulatok egymás utáni sorrendjében hajtották végre az összeszerelési feladatot:

1. Elővettek egy csavart az egyik kezükkel, a másikkal rárakták az alátétet, majd csavarfejjel lefelé félre rakták. Ezt a másik két csavarral is megismételték.

2. Elővették a lemezt és az egyik kezükben tartották, a másikkal pedig összefogva a csavart az alátéttel egyenként belehelyezték.

3. Ezután a lemezt megforgatták és lerakták úgy, hogy a három csavar ne essen ki belőle, vagyis a másik kezükkel alátámasztották.

4. Az alátétek következtek, innentöl már kicsivel könnyebben haladt a folyamat.

5. Ráhelyezték a lemezt, majd utána ismét egyesével rárakták az alátéteket.

6. Utolsó mozdulatként az anyák rácsavarása, majd a késztermék tartóba való helyezése következett.

\section{Az előtervezés nélküli szerelési folyamat nehézségei:}

- főként csak az egyik kéz dolgozott,

- egy dobozba beleszórt alkatrészeket kellett kivenni, ami több időt és odafigyelést igényel,

- az összeszerelés körülményes, nem megy gördülékenyen, ezáltal hosszú az ehhez szükséges idő.

\subsection{A szerelési folyamat tervezése és elvégzése az MTM módszer alkalmazásával}

Az előzőekben bemutatott folyamat hatékonyságának javítása érdekében a munkafolyamat MTM módszer megtervezésével történt. Az MTM alkalmazásának célja, hogy mind a két kezet megfelelően összehangolva alkalmazzuk.

\section{A szerelési feladat kiindulási állapota:}

- Az alkatrészek tárolására három, egymás mellett elhelyezkedő egyenkénti adagoló áll rendelkezésre, a szerelést végrehajtó személytől $30 \mathrm{~cm}$ távolságban.

- Egyenkénti alkatrész-bevezetés alatt értendő minden olyan eset, amikor az egyes munkadarabokat a dolgozó számára úgy biztosítják, hogy azt válogatni ne kelljen, hanem egy mozdulattal, könnyedén kiemelhető legyen az alkatrész-bevezetőből.

- Egy ülék (szerelést segítő pozicionáló eszköz) lett kialakítva, ami arra szolgál, hogy a csavarok nem mozduljanak el, és ez lehetővé teszi a két kéz párhuzamos használatát a szerelésben. A 4. fejezetben vázolt kódok alapján világosan látható, hogy az elkevert, vagy egyenként bevezetett alkatrészek elvétele hány másodpercet vesz igénybe. Ezek az értékek természetesen átlagosak, egy gyakorlott, tapasztalt dolgozó számára akár kevesebb időt is igénybe vehetnek az adott folyamatok. 


\begin{tabular}{lllllllll|}
\multicolumn{1}{l}{ Nyúlás } & \multicolumn{3}{c}{ Megfogás } & \multicolumn{3}{c|}{ Összesen } \\
\hline Kód & TMU & Sec & Kód & TMU & Sec & TMU & Sec \\
$R 30 A$ & 9,5 & 0,3 & $G 1 A$ & 2,0 & 0,1 & 11,5 & $\mathbf{0 , 4}$ \\
$R 30 C$ & 14,1 & 0,5 & G4B & 9,1 & 0,3 & 23,2 & $\mathbf{0 , 8}$ \\
\hline
\end{tabular}

4.ábra Összehasonlítás MTM szerint

A fenti 4. ábrából látható, hogy ha az alkatrészek $30 \mathrm{~cm}$ távolságban helyezkednek el, a dobozból egy darab alkatrész kivétele 0,8 ; míg ugyanennek az alkatrésznek a bevezetőből egyenként való kivétele 0,4 másodpercet vesz igénybe. Az alkatrészek egyenként való bevezetésével a nyúlás és a megfogás ideje tehát körülbelül a felére csökkenthetö.

Az egyenkénti adagolók két oszlopban helyezkednek el (a jobb és a bal kéznél), valamint kétszintesek. Alul a csavarokat, felül pedig az alátéteket adagolják. Jobb oldalt pedig a lemezek helyezkednek el, azonban a nagy felületük miatt nem számottevő, hogy ládából vagy egyenkénti adagolókból történik az elvételük.

A folyamat megtervezése után MTM kódkártyát kell készíteni, aminek segítségével jól átlátható a szerelési folyamatok sorrendje (7. táblázat). A jobb és a bal oszlop a jobb, illetve bal kéz mozdulatát írja le. A „, ’ jel pedig akkor van jelen, mikor a két kéz ugyanazt a mozdulatot végzi.

7.1. táblázat Az adott szerelési folyamat tervezése MTM módszerrel Leírás freq $[\mathrm{TMU}] \quad[\mathrm{s}]$ freq num Kode Leírás

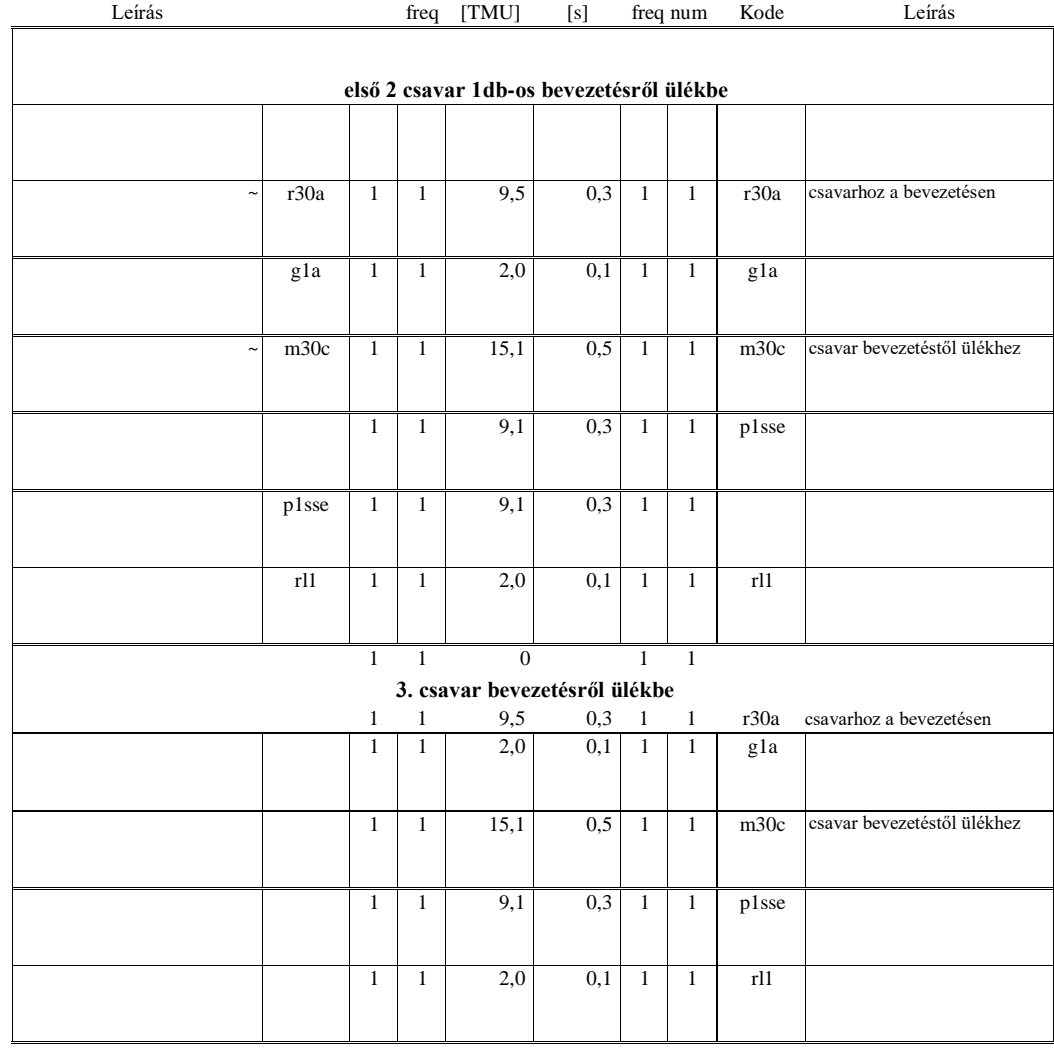




\begin{tabular}{|c|c|c|c|c|c|c|c|c|c|}
\hline & & 1 & 1 & 0 & & 1 & 1 & & \\
\hline & Iső 2 alát & t $1 d$ & $-\mathbf{o s}$ & ezetésr & z ülék & ben & lévö & savarol & \\
\hline$\sim$ & $\mathrm{r} 30 \mathrm{a}$ & 1 & 1 & 9,5 & 0,3 & 1 & 1 & $\mathrm{r} 30 \mathrm{a}$ & alátéthez a bevezetésen \\
\hline & g1a & 1 & 1 & 2 2,0 & \begin{tabular}{l|l}
0,1 \\
\end{tabular} & 1 & 1 & g1a & \\
\hline$\sim$ & $\mathrm{m} 30 \mathrm{c}$ & 1 & 1 & 15,1 & 0,5 & 1 & 1 & $\mathrm{~m} 30 \mathrm{c}$ & \begin{tabular}{|lll}
$\begin{array}{l}\text { alátét az } \\
\text { csavarhoz }\end{array}$ & ülékben lévö \\
\end{tabular} \\
\hline & p1se & 1 & 1 & 5,6 & 0,2 & 1 & 1 & p1se & \\
\hline & rl1 & 1 & 1 & 2,0 & 0,1 & 1 & 1 & rl1 & \\
\hline & & 1 & 1 & 0 & & 1 & 1 & & \\
\hline & 3. alátét & $1 \mathrm{db}$ & $\mathbf{s} \mathbf{b}$ & zetésröl & ülékb & en lé & vö cs & varokr & \\
\hline & & 1 & 1 & 9,5 & 0,3 & 1 & 1 & $\mathrm{r} 30 \mathrm{a}$ & alátéthez a bevezetésen \\
\hline & & 1 & 1 & 2,0 & 0,1 & 1 & 1 & g1a & \\
\hline & & 1 & 1 & 15,1 & 0,5 & 1 & 1 & $\mathrm{~m} 30 \mathrm{c}$ & \begin{tabular}{|lll}
$\begin{array}{l}\text { alátét az ülékben } \\
\text { csavarhoz }\end{array}$ & lévö \\
\end{tabular} \\
\hline & & 1 & 1 & 5,6 & 0,2 & 1 & 1 & p1se & \\
\hline & & 1 & 1 & 2,0 & 0,1 & 1 & 1 & rll & \\
\hline & lemez 1c & -os & eve & sröl a s & elöülé & kbe & lév & csavar & okra \\
\hline & & 1 & 1 & 9,5 & 0,3 & 1 & 1 & $\mathrm{r} 30 \mathrm{a}$ & lemezhez a bevezetésen \\
\hline & & 1 & 1 & 2,0 & 0,1 & 1 & 1 & g1a & \\
\hline & & 1 & 1 & 15,1 & 0,5 & 1 & 1 & $\mathrm{~m} 30 \mathrm{c}$ & lemez bevezetésröl az ülékhez \\
\hline & & 1 & 1 & 14,7 & 0,5 & 1 & 1 & p1ssd & $\begin{array}{l}\text { d - óvatosan kell illeszteni, h } \\
\text { ne mozduljanak el a csavarok } \\
\text { az ülékben }\end{array}$ \\
\hline & & 1 & 1 & 2,0 & 0,1 & 1 & 1 & rll & \\
\hline & & 1 & 1 & 0 & & 1 & 1 & & \\
\hline 2. alátét & szint - el & 02 & átét & b-os be & etésrö & laz & ilékl & en lévő & csavarokra \\
\hline$\sim$ & $\mathrm{r} 30 \mathrm{a}$ & 1 & 1 & 9,5 & 0,3 & 1 & 1 & $\mathrm{r} 30 \mathrm{a}$ & alátéthez a bevezetésen \\
\hline & g1a & 1 & 1 & 2,0 & 0,1 & 1 & 1 & g1a & \\
\hline & $\mathrm{m} 30 \mathrm{c}$ & 1 & 1 & 15,1 & \begin{tabular}{l|}
0,5 \\
\end{tabular} & 1 & 1 & $\mathrm{~m} 30 \mathrm{c}$ & \begin{tabular}{|l}
$\begin{array}{l}\text { alátét az } \\
\text { csavarhoz }\end{array}$ \\
\end{tabular} \\
\hline & p1se & 1 & 1 & \begin{tabular}{l|}
5,6 \\
\end{tabular} & 0,2 & 1 & 1 & p1se & \\
\hline & rl1 & 1 & 1 & 2,0 & 0,1 & 1 & 1 & rl1 & \\
\hline & & 1 & 1 & 0 & & 1 & 1 & & \\
\hline
\end{tabular}




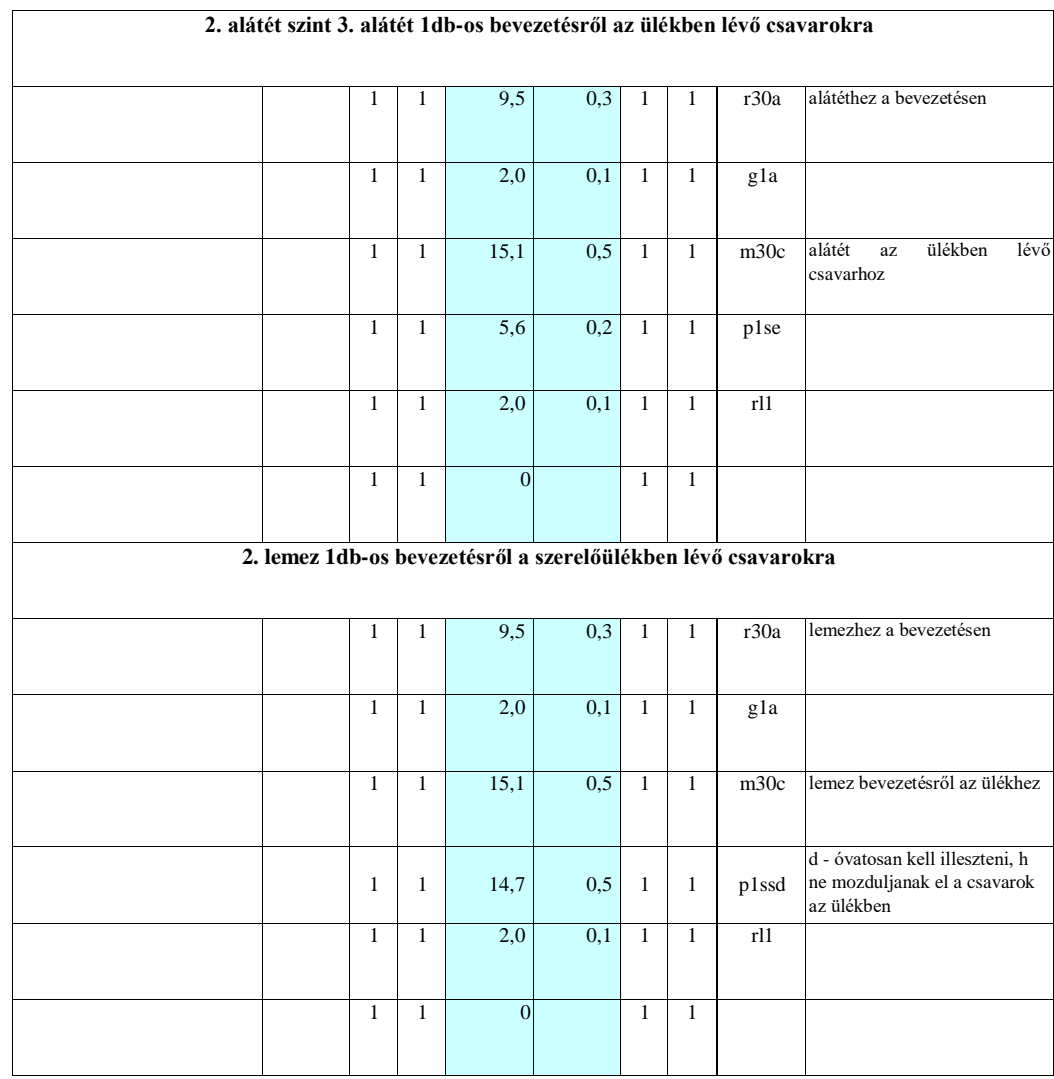

7.2. táblázat Az adott szerelési folyamat tervezése MTM módszerrel

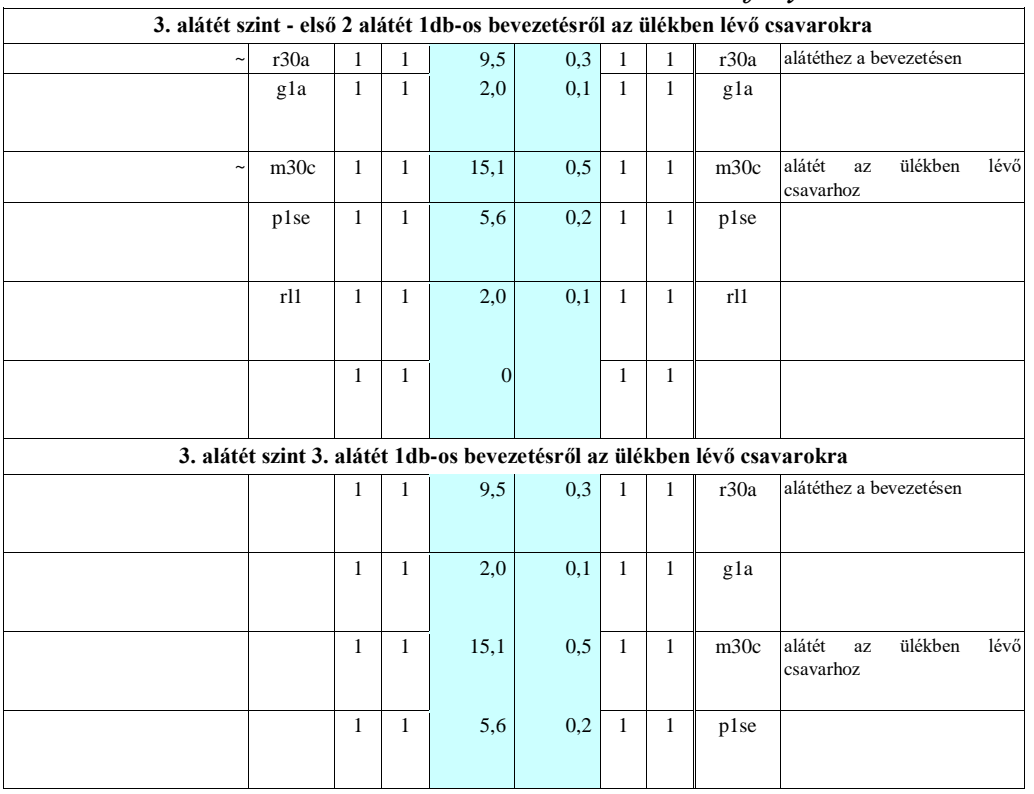




\begin{tabular}{|c|c|c|c|c|c|c|c|c|c|}
\hline & & 1 & 1 & \multirow{2}{*}{$\begin{array}{r}2,0 \\
0 \\
0\end{array}$} & \multirow[t]{2}{*}{0,1} & 1 & 1 & \multirow[t]{2}{*}{ rl1 } & \\
\hline & & 1 & 1 & & & 1 & 1 & & \\
\hline \multicolumn{10}{|c|}{ első 2 anya az 1db-os bevezetésekrốl az ülékben lévő elógyártmányra } \\
\hline & r30a & 1 & 1 & 9,5 & 0,3 & \begin{tabular}{|l|}
1 \\
\end{tabular} & 1 & $\mathrm{r} 30 \mathrm{a}$ & $\begin{array}{l}\begin{array}{l}\text { anyához az egydarabos } \\
\text { bevezetésen }\end{array} \\
\text { a }\end{array}$ \\
\hline & g1a & 1 & 1 & 2,0 & 0,1 & 1 & 1 & g1a & \\
\hline & $\mathrm{m} 30 \mathrm{c}$ & 1 & 1 & 15,1 & 0,5 & 1 & 1 & $\mathrm{~m} 30 \mathrm{c}$ & $\begin{array}{l}\begin{array}{l}\text { anya az elógyártmány } \\
\text { csavarjăhoz }\end{array} \\
\end{array}$ \\
\hline & & 1 & 1 & 16,2 & 0,6 & 1 & 1 & p2se & \\
\hline & & 1 & 1 & 2,0 & 0,1 & 1 & 1 & $\mathrm{~m} 2 \mathrm{~b}$ & menetkeresés \\
\hline & p2se & 1 & 1 & 16,2 & 0,6 & 1 & 1 & & \\
\hline \multirow[t]{7}{*}{ menetkeresés } & $\mathrm{m} 2 \mathrm{~b}$ & 1 & 1 & 2,0 & 0,1 & 1 & 1 & & \\
\hline & rl1 & 1 & 1 & 2,0 & 0,1 & 1 & 1 & rl1 & \\
\hline & $\mathrm{r} 2 \mathrm{a}$ & 1 & 1 & 6,0 & 0,2 & 1 & 3 & $\mathrm{r} 2 \mathrm{a}$ & anyához \\
\hline & g1a & 1 & 1 & 6,0 & 0,2 & 1 & 3 & g1a & \\
\hline & $\mathrm{m} 2 \mathrm{~b}$ & 1 & 1 & 6,0 & 0,2 & 1 & 3 & $\mathrm{~m} 2 \mathrm{~b}$ & anyát csavarra "teker" \\
\hline & rl1 & 1 & 1 & 6,0 & 0,2 & 1 & 3 & rl1 & \\
\hline & & 1 & 1 & 0 & & 1 & 1 & & \\
\hline \multicolumn{10}{|c|}{ 3. anya az 1db-os bevezetésekrôl az ülékben lévő elögyártmányra } \\
\hline & & 1 & 1 & 9,5 & 0,3 & 1 & 1 & r30a & $\begin{array}{l}\text { anyához az egydarabos } \\
\text { bevezetésen }\end{array}$ \\
\hline & & 1 & 1 & 2,0 & 0,1 & 1 & 1 & g1a & \\
\hline & & 1 & 1 & 15,1 & 0,5 & 1 & 1 & $\mathrm{~m} 30 \mathrm{c}$ & $\begin{array}{l}\text { anya az elögyártmány } \\
\text { csavarjához }\end{array}$ \\
\hline & & 1 & 1 & 16,2 & 0,6 & 1 & 1 & p2se & \\
\hline & & 1 & 1 & 2,0 & 0,1 & 1 & 1 & $\mathrm{~m} 2 \mathrm{~b}$ & menetkeresés \\
\hline & & 1 & 1 & 2,0 & 0,1 & 1 & 1 & rl1 & \\
\hline & & 1 & 1 & 2,0 & 0,1 & 1 & 1 & $\mathrm{r} 2 \mathrm{a}$ & anyához \\
\hline & & 1 & 1 & 2,0 & 0,1 & 1 & 1 & g1a & \\
\hline & & 1 & 1 & 2,0 & 0,1 & 1 & 1 & $\mathrm{~m} 2 \mathrm{~b}$ & anyát csavarra "teker" \\
\hline & & 1 & 1 & 2,0 & 0,1 & 1 & 1 & rll & \\
\hline & & 1 & 1 & 0 & & 1 & 1 & & \\
\hline
\end{tabular}




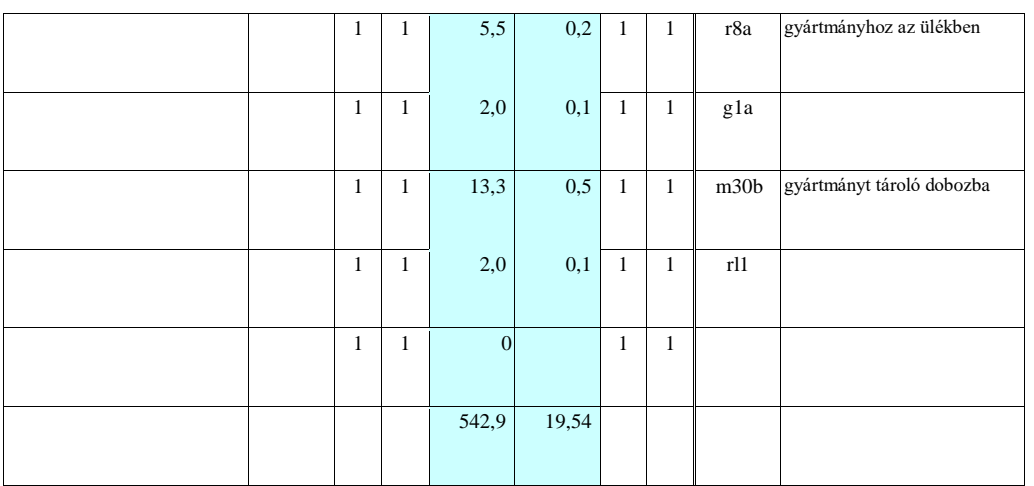

\section{A folyamatfejlesztés eredménye - az esettanulmány kiértékelése}

Az 5. fejezetben ugyanazon szerelési müveletsor MTM módszerrel és a módszer alkalmazása nélkül elvégzett folyamatát mutattuk be. Összehasonlítva a két esetet, megvizsgáljuk a szerelési folyamatok ciklusidejeit, valamint az egy müszak alatt elöállítható termékek darabszámát.

Az MTM módszer alkalmazása nélkül elvégzett folyamat ciklusideje 25,36 másodperc, míg az MTM módszer alkalmazásával elvégzett folyamat esetén pedig az MTM kódkártyáról leolvasható, hogy 19,54 másodperc a késztermék elkészítésének a ciklusideje. Egy 8 órás müszakban a 480 perces bruttó munkaidő 20 perces ebédszünet és $8 \mathrm{db}$ óránkénti 5 perces szünet levonása után a nettó munkaidő 420 perc $(25200 \mathrm{sec})$. A nettó munkaidő és a kalkulált ciklusidők felhasználásával kiszámíthatóak a müszakonként előállítható késztermék-darabszámok a két esetre, amelyeket az 5. ábra foglal össze.

\begin{tabular}{|c|c|c|}
\hline Szerelési folyamat & Ciklusidó $[\mathrm{sec} / \mathrm{db}]$ & $\begin{array}{c}\text { Legyártható késztermékek } \\
\text { mennyisége [db/müszak] }\end{array}$ \\
\hline MTM eljárás nélkül & 25,36 & 993 \\
\hline MTM eljárással & 19,54 & 1289 \\
\hline Mutatók javulása: & $-23 \%$ & $\mathbf{+ 2 9 , 8 \%}$ \\
\hline
\end{tabular}

5. ábra A folyamatfejlesztés eredménye

Ezzel pedig az egy müszakban legyártható munkadarabok számát 993 db-ról 1289 db-ra növeltük, amely $29,8 \%$-os hatékonyságjavulást jelent.

\section{7. Összefoglalás}

Amikor napi több száz, több ezer legyártott, összeszerelt munkadarab gördül le a futószalagokról, kerül ki a gyártósorokról, minden tényezőt figyelembe kell venni a gyártási idő csökkentése érdekében, még ha az minimális átfutási időcsökkenést is eredményez. Ezek az akár tized-, sőt századmásodperces változtatások ugyanis végül percekké, órákká adódnak össze, amely a gyártásban a darabszám jelentős növekedésével, illetve profitnövekedéssel jár. 
Ha a dolgozó egy termék szerelése során végzett munkafolyamatát rövidebb átfutási idővel végzi el, az egy müszak alatt akár jelentős termelékenységnövekedést is eredményezhet. Az ilyen finom időkülönbségek meghatározását könnyíti meg az MTM módszer. Ez a módszer - hatékonyságának köszönhetően - nagyon elterjedt az egész világon, ezért is fontos, hogy a gyártási folyamatok szervezésével foglalkozó szakemberek helyesen tudják a módszert alkalmazni.

A cikkben ismertetésre került az MTM időelemzés módszerének elmélete, valamint egy esettanulmány bemutatásával - egy adott késztermék elkészítése MTM módszerrel - az is igazolva lett, hogy az MTM módszer alkalmazásával jelentős mértékü hatékonyságnövekedés érhető el a szerelési folyamatokban.

\section{Köszönetnyilvánítás}

A cikkben ismertetett kutató munka az EFOP-3.6.1-16-2016-00011 jelü „Fiatalodó és Megújuló Egyetem - Innovatív Tudásváros - a Miskolci Egyetem intelligens szakosodást szolgáló intézményi fejlesztése" projekt részeként - a Széchenyi 2020 keretében - az Európai Unió támogatásával, az Európai Szociális Alap társfinanszírozásával valósul meg.

\section{Irodalomjegyzék}

[1] Cselényi, J., Illés, B. (szerk.): Logisztikai rendszerek I., Miskolci Egyetemi Kiadó, Miskolc, 2004., ISBN 9636616728

[2] Kovács, Gy.: Methods for efficiency improvement of production and logistic processes, Research Papers Faculty of Materials Science and Technology in Trnava, 26 No. 42 (2018) pp.4546. https://doi.org/10.2478/rput-2018-0006

[3] Straka, M.: The position of distribution logistics in the logistic system of an enterprise, Acta logistica, 4 No.2 (2017) pp.23-26. https://doi.org/10.22306/al.v4i2.5

[4] Bley, H., Reinhart, G., Seliger, G., Bernardi, M., Korne T.: Appropriate human involvement in assembly and disassembly, CIRP Annals, 53 No. 2 (2004) pp.487-509. https://doi.org/10.1016/S0007-8506(07)60026-2

[5] Kardos, K., Jósvai, J.: Gyártási folyamatok tervezése, Jegyzet, 2006. http://rs1.sze.hu/ josvai/GYFT_HEFOP_2006.pdf

[6] Mikó, B., Molnár, Zs.: Szerelés hatékonyan - Eszközök szerelési folyamat tervezéséhez, elemzéséhez, Gyártástrend, 12 (2012) pp.38-41.

[7] Maynard, H.B., Stegemerten, G.J., Schwab, J.L.: Methods time-measurement, McGraw Hill, New York, 1948., ISBN 9781258350987

[8] Cimino, A., Longo, F., Mirabelli, G., Papoff, E.: MOST and MTM for work methods optimization, 2008 10th International Workshop on Harbor, Maritime and Multimodal Logistics Modeling and Simulation, Italy, pp.35-41.

[9] Deutsche MTM-Vereinigung e. V.: MTM-1 Tananyag, REFA-Hungária Alapítvány

[10] Németh, T.: Gépipari szerelés, Müszaki Könyvkiadó, Budapest, 1973. 